Forthcoming in NS Megoran, F McConnell and P Williams (eds), 'The geographies of peace: New approaches to boundaries, diplomacy and conflict resolution', I.B. Tauris \& Co Ltd

\title{
Unearthing the local: Hegemony and Peace Discourses in Central
}

\section{Africa}

\section{Patricia Daley}

\section{Introduction}

This chapter is concerned with how an ostensibly western construction of peace has acquired hegemonic authority in the global sphere, and the implications of this for nonwestern experiences of peace. I argue that when transposed to the African context, this hegemonic peace promotes norms and practices that are counter to local notions of peace, contributing to persistent insecurity after peace agreements have been signed and peacebuilding is instituted. Critics of post-conflict interventions in post-Cold War Africa highlight the failure of the universalized liberal peace to de-militarize areas affected by civil wars and to effect transformative and emancipatory changes to the lives of the impoverished masses. Policy makers have responded to critics by incorporating the local into the 'liberal peace' agenda through engagement with non-governmental organizations (NGOs) and resurrecting traditional justice institutions. Such additions leave the 'liberal peace' largely intact, unchallenged in its hegemony, and assured by a nexus of donors, peace industry professionals and state elites.

Our understanding of peace and how it can be achieved varies with our position in relation to structures of power, both socially and spatially. In the west, feminist critics have highlighted the gendered biases of the liberal peace. ${ }^{i}$ In the non-western world, its appropriateness remains under-theorized and little space has been given to exploring the content of a local, contextualized, everyday peace, in light of scholarly recognition of the 
Forthcoming in NS Megoran, F McConnell and P Williams (eds), 'The geographies of peace: New approaches to boundaries, diplomacy and conflict resolution', I.B. Tauris \& Co Ltd

situatedness of knowledge and that, as Williams \& McConnell note, peaceful co-

existence depends on a range of 'everyday acts and practices', and on processes

operating 'in distinct situated contexts. ${ }^{\text {ii }}$

According to Emmanuel Hansen, 'the perspective which a group brings to the peace problematic depends on its history and material conditions as well as the position of the group within the power structure of national or international systems. ${ }^{\text {,iii }}$ Hansen, in making a case for an African perspective on peace during The Cold War, argues that peace and security in mainstream Euro-American thought is minimalist and based on fear and mutual distrust. Such thinking became globalized through colonialism and institutionalized in the global structures of governance that emerged after the Second World War. It was supported and tolerated by many, as modernity held out the promise of the 'liberation of human beings from physical want' - the question is whether such freedom is perceived by those with power as socially and globally inclusive. Recognition of global power differentials have led to calls for a feminist geopolitics ${ }^{\text {iv }}$ which, Hyndman argues, should take into consideration an 'embodied political vision'; in essence an 'analytic and politics that is contingent upon context, place and time." Such a stance enables questioning of the dominant geo-political narrative and may reveal how ordinary non-western people challenge the imaginative geographies of themselves as others and create spaces of peace, as Megoran concludes, 'out of the most unlikely political geographical rock faces. ${ }^{\text {vi }}$

Central African states provide a space to study the limitations of externallyderived liberal peace and the necessity of articulating a progressive conceptualization of peace that is localised, feminist and culturally contextual. Wars and genocidal violence in the Democratic Republic of Congo (DRC), Burundi and Rwanda ${ }^{\text {vii }}$ during the last decade of the twentieth century were followed by internationally and regionally-sponsored peace negotiations and peace and ceasefire agreements. ${ }^{\text {viii }}$ Since the beginning of the twenty- 
Forthcoming in NS Megoran, F McConnell and P Williams (eds), 'The geographies of peace: New approaches to boundaries, diplomacy and conflict resolution', I.B. Tauris \& Co Ltd

first century, these states have been undergoing internationally-assisted post-conflict

reconstruction. However, civilians remain vulnerable to rebel and state-sponsored direct violence, including sexual violence, and extreme material deprivation.

The main proposition of this chapter is that the failure of the post-Cold War liberal peace in Central Africa can be attributed to its attempt to universalize the cultural values of modernity and neo-liberalism, whilst being bolstered by western military superiority and geo-political interests. It is through such processes that local cultures of peace are marginalized. This chapter is organized around four sections. First, I argue that the liberal peace in the African context privileges top-down political, economic and technical reforms rather than transformation. Second, that it leads to the further embedding of militarism and patriarchy in African societies. The liberal peace is shown to prioritize a violent, masculine form of militarism which sits incongruously with its simultaneous concern for gender equality. For example, UN Resolution 1325 encourages the integration of women into peacemaking and peace-building without fundamentally challenging patriarchal structures. ${ }^{\text {ix }}$ Thirdly, the liberal peace fails to understand local life and cultures and discounts the pre-colonial experience. When the 'local' is integrated into the liberal peace, the emphasis is on resurrecting patriarchal 'traditional' justice structures, such as the' 'Council of Wise Men' (bashingantahe in Burundi or Gacaca in Rwanda), which, even in their modern form, contradict the liberal peace policy of gender equity and run counter to local 'established societal practices.' Nevertheless, this is not an argument for a singular African perspective on peace because of the continent's diverse local histories and cultures. In the final section, I consider what the content of a locally-situated peace might look like, drawing on debates in African peace scholarship and feminist activism that seek to articulate an African feminist perspective of peace that is simultaneously contextual and emancipatory. 
Forthcoming in NS Megoran, F McConnell and P Williams (eds), 'The geographies of peace: New approaches to boundaries, diplomacy and conflict resolution', I.B. Tauris \& Co Ltd

Theoretically, this chapter draws on Gramscian notions of hegemony to articulate the dominance of the liberal peace discourse in the region; Foucauldian concepts of biopolitics as a form of governance that relies on hierarchies of human beings; and Hill Collins' use of the concept of intersectionality as an analytical tool to show how oppressions, in this case structural, racial and gendered, work together to produce injustice in particular locales. ${ }^{\mathrm{xi}} \mathrm{I}$ argue that with its roots in western modernity, the hegemonic liberal peace, based on a rational, militarized, gendered and racialized conceptualization, runs counter to the societal transformation and healing that African societies crave. Here, I utilise the African concept of ubuntu to explore the potentialities for localised and collectivised approaches to peace.

Evidence for this chapter is derived from multiple sources; partly from fieldwork in Burundi in 2006, involving interviews with local key informants, representatives from UN agencies and local and international NGOs, and, since then, analysis of human rights reports, media sources for Burundi and the DRC, and reviews of scholarly articles.

\section{Unpacking the liberal peace: the roots of its hegemony in Africa}

Drawing from the scholarship of Duffield and Kaldor, the term 'liberal peace' defines the emergence of a perspective on peaceful co-existence that separates territory/state from civil society, that interprets state militarism as security, and that is differentiated hierarchically in its global reach. ${ }^{\text {xii }}$ While the liberal peace is seen as resulting from the emergence of discursive liberal governance in the late modern period, at its core are ideologies and values that have deep historical roots - both colonial and modern. Of relevance here are three aspects of the liberal peace that are at odds with an African understanding of peace: its privileging of the territorial security of the state above that of the well-being of citizens; its embodied gendered dimension of national security and 
Forthcoming in NS Megoran, F McConnell and P Williams (eds), 'The geographies of peace: New approaches to boundaries, diplomacy and conflict resolution', I.B. Tauris \& Co Ltd

militarism; and the ways in which its global expansion is interconnected with imperialism and the racialized 'other'.

The historical roots of the liberal peace originate in the experience of warfare in Europe and the emergence of the nation-state ideal in the seventeenth century. ${ }^{\text {xii }}$ Classical European scholarship, such as that represented by Max Weber, which maintains that wars are fought by states and civil wars result from the loss of state monopoly of

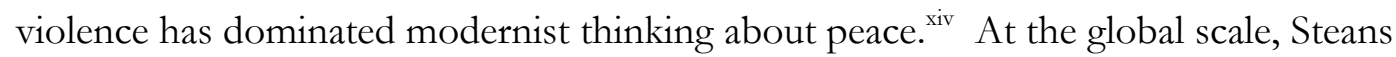
notes that 'hegemonic states dominate international institutions and, in this way, "manage" international security, [assuming that] the security of one state is closely, inextricably even, linked with the security of other states. ${ }^{\mathrm{xv}}$ This model was universalized with the establishment of the United Nations (UN) and its key institution - the Security Council - and has a central role in shaping the global peace architecture. Western states are supported by an intellectual and popular culture that produces and maintains imaginative geographies about other spaces and peoples that legitimizes their actions. Since the Second World War, the UN has established international norms governing the promotion of peace and security, which frame the peace discourse of policy makers, scholars and activists. Gramsci's concept of hegemony partly explains the universalizing of western elites' concept of peace. ${ }^{\text {xvi }}$ Hegemony does not arise purely from the use of physical power, but from the ability to impose your world view onto others less powerful. Following Gramsci, I propose that the western professional peace industry has been able to insert its understanding of 'social life' into the liberal peace because of the 'prestige' and 'confidence' that it 'enjoy(s) in the world. 'xvii Such meta-narratives, concerning peace and security, have been applied and adopted in particular ways within Africa.

Since the 1960s, neo-realists have equated national security in Africa with state militarism and territoriality. Africans have accepted the liberal peace because of the 
Forthcoming in NS Megoran, F McConnell and P Williams (eds), 'The geographies of peace: New approaches to boundaries, diplomacy and conflict resolution', I.B. Tauris \& Co Ltd

material resources that the west can bring forth to stop warfare and facilitate

reconstruction. Peace processes have been driven largely by western aid donors whose investments are shaped by their geo-political and economic interests. During The Cold War, proxy wars helped to maintain the peace in Europe and North America. Western states' perception of threats to global peace varies historically; throughout The Cold War it was communist expansionism and nuclear proliferation, then, after 11 September 2001, amorphous groups that can be labelled 'terrorists' and 'rogue states'. Since the start of the War on Terror, the USA has perceived its security as being dependent on greater intervention in Africa, leading to the further militarization of African states under the United States Trans-Sahel Initiative and Africa Command. ${ }^{\text {xviii }}$

Securing the physical territory of the state against the material well-being of its citizens produces a dichotomy that Johan Galtung terms 'negative' and 'positive' peace. ${ }^{\text {xix }}$ The former refers to the ending of direct violence (physical combat), whilst the latter refers to a more holistic state of being in which those conditions that may lead to the breakdown of society and the pursuance of war (structural violence), are eradicated. The international framing of peace for Africa has not implied the absence of direct and structural violence. International peacemaking in Central Africa is mired with failures to even promote negative peace. International interventions, such as in Katanga, Congo (1960) and Rwanda (1994), have fallen short of putting in place the mechanisms needed to prevent either the escalation of violence or to promote positive peace. In the case of Rwanda, while supporting the Arusha Peace Agreement with Security Council Resolution 868 of 29 September 1993 and the despatch of 2700 peacekeepers, the UN mission lacked the mandate to intervene in the 1994 genocide and its number was reduced to 270 at a critical moment when it could have saved lives. ${ }^{\mathrm{xx}}$ Almost ten years later, in DRC and Burundi, UN peacekeepers were neither able to avert the killing of 1000 people in Ituri, DRC (April 2003) and the massacres of 152 refugees in Gatumba, Burundi (August 
Forthcoming in NS Megoran, F McConnell and P Williams (eds), 'The geographies of peace: New approaches to boundaries, diplomacy and conflict resolution', I.B. Tauris \& Co Ltd

2004) nor to prevent the persistence of human rights violations in these states, including the scale of sexual violence in the Eastern DRC. ${ }^{\mathrm{xxi}}$

Galtung's influential peace/violence dichotomy remains essentially a liberal interpretation and has been criticized for its lack of attention to gender inequalities as a form of violence - a factor which pre-disposes a society to war. ${ }^{x x i i}$ Feminist scholarship has demonstrated the interconnectedness of militarism, national security and patriarchy in the modern state. ${ }^{\text {xiii }}$ Militarism is reliant on the promotion of hypermasculinity - a stereotypical form of masculine behaviour and attributes with exaggerated characteristics, such as aggression and the ability to perpetuate extreme violence. ${ }^{\text {xiv }}$ Such forms of masculinity are central to state instability and outbreaks of violence. ${ }^{x x v}$ Recent policies to incorporate women into militaries and to gender-sensitize peacekeepers have not resulted in any significant shift in ideology. ${ }^{\text {xxi }}$

With the potential for violence against the female body, women have become stereotyped as being symbolic of the nation and in need of protection. ${ }^{\text {xxvii }}$ However, such vulnerability is not extended to all women, who are differentiated hierarchically by class, race, ethnicity and age. Hill Collins' concept of intersectionality becomes a useful analytical tool to understand how gender intersects with race and class in particular spaces of oppression. ${ }^{\text {xviii }}$ Also useful is Foucault's concept of 'biopolitics', which he refers to as a set of processes by which the modern state attempts to regulate human life. This centres on the construction of the people as population, producing a rational, measurable and hierarchical category. For Foucault, modern racism (dating from the nineteenth century) became a 'technique of power' that depicts other races as threats to the population. It acts as the ultimate 'mechanism that allows biopower (sovereignty over death and regulation of life) to work', so that 'in a normalizing society, race or racism is

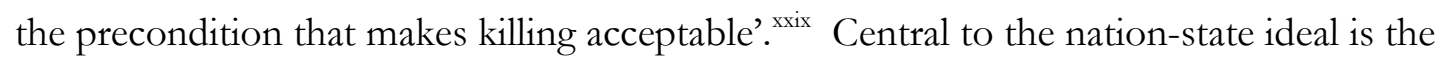
emphasis on racial and cultural homogeneity as prerequisites for a peaceful and stable 
Forthcoming in NS Megoran, F McConnell and P Williams (eds), 'The geographies of peace: New approaches to boundaries, diplomacy and conflict resolution', I.B. Tauris \& Co Ltd

society. This places discriminatory practices at the ideological core of the modern state.

Though racism is considered abhorrent in international arenas, racial hierarchy underlies how people in different geographical spaces are represented and treated, even in the context of peacekeeping. ${ }^{\mathrm{xx}}$ In western popular discourse, Africa has become a space where normal rules do not apply and people are de-humanized. Romeo Dallaire, the UN military general in charge of the peacekeepers in Rwanda during the genocide, was told that 'the lives of 800,000 Rwandans were only worth risking the lives of ten American troops. ${ }^{\text {xxxi }}$

European biopolitical conceptualizations of peace entered Central Africa during the period of colonial conquest when colonial militaries were established for pacification and the subjugation of people to foreign rule. 'Pacification' was often constituted as a violent act whereby, through force, the foreign power could instil fear as a means of domination, a tactic which sometimes involved the destruction of whole communities. .xxii $^{\text {. }}$ For many Africans, the externally imposed peace that came with pacification meant the loss of control over territory and subjection to violence of genocidal proportions and other de-humanizing practices, justified by colonial biopolitics, which institutionalized racial and ethnic differences within the colonial state.

Nationalists seeking to forge modern nation-states in post-independence Africa discounted difference, especially ethnicity, representing it as a hindrance to modernization. Consequently, political and social mechanisms to deal with diversity in modern African states are underdeveloped theoretically. ${ }^{x x x i i i}$ This vacuum has led to the perpetuation of models of the state, even under the liberal peace, that rest upon supposedly normative practices of discrimination and inherent instability, which in Central Africa contributed to genocide against those Africans constructed as 'nonindigenous.' 
Forthcoming in NS Megoran, F McConnell and P Williams (eds), 'The geographies of peace: New approaches to boundaries, diplomacy and conflict resolution', I.B. Tauris \& Co Ltd

Realist solutions to the failings of the liberal peace vary from more intense and protracted military intervention and exercising a trusteeship role over the 'non-liberal others', to co-opting local elite institutions. For Richmond, localising peace should mean moving beyond elite interests and penetrating the everyday lives of ordinary people to produce a liberal-local hybrid - a 'post-liberal peace'- that combines the benefits of the liberal peace with attention to 'cultures, societies and identities. ${ }^{\text {xxxiv }}$ However, the ontological shift that is needed in order to tap into the peaceful energies in African society lies outside the framework of western conceptualizations of modernity, rationality, governance and security. In contrast, I suggest that a feminist critique, with its focus on intersectionality, allows some exploration of a peaceful world beyond militarism, masculinism and racial 'othering'.

\section{Limitations of the liberal peace in Central Africa}

The central contention here is that the liberal peace is antithetical to the promotion of positive peace in Central Africa. Its implementation is done in a formulaic, technocratic and managerial fashion, often focusing on top-down interventions which tend to be either reform or palliative in nature. Two aspects stand out: its privileging of political and economic reforms - rather than transformation - at the level of the state, and its role in further embedding militarism and patriarchy within post-conflict societies.

Theories of late twentieth century African wars are informed by a biopolitical discourse that interprets them as 'new' and 'non-ideological' - the consequence of innate flaws in African societies. ${ }^{\mathrm{xxv}}$ Rather than see such wars as the consequence of capitalist modernity, such interpretations re-traditionalize wars by representing them as essentially tribal, often arising from age-old enmities or entrenched inequalities based on ethnicity, race or religion. Even when interpretations attempt to avoid ethnic reductionism, they 
Forthcoming in NS Megoran, F McConnell and P Williams (eds), 'The geographies of peace: New approaches to boundaries, diplomacy and conflict resolution', I.B. Tauris \& Co Ltd

nevertheless commonly resort to simplistic arguments about the greed of ethnic elites or 'warlords', who seek to capture state resources for private gain. ${ }^{\text {xxxi }}$

A popular post-Cold War liberal peace solution to the problem of multi-ethnicity and other forms of difference in Africa is power-sharing. ${ }^{\text {xxvii }}$ Here, the institutions of governance are divided between political parties, ethnic elites and rebel movements as a precursor to liberal state-building. In practice, elites and rebels prefer to negotiate themselves into power-sharing deals rather than commit themselves to the electorate. Power-sharing does not lead to any radical changes in the nature of the state and often encourages 'insurgent violence. ${ }^{\text {xxxviii }}$ In the DRC and Burundi, power-sharing favoured those with military might. It led to an intensification of the fighting, especially against civilians, which was used as a bargaining tool in peace and ceasefire negotiations. Crucially though liberal, state-building at the national level tends to ignore local competition and conflicts, leaving them unresolved. ${ }^{\text {xxix }}$ Such conflicts, such as access to land and power struggles between local elites, remain as stumbling blocks to peace in the post-conflict phase.

At the national level post-conflict reconstruction provides the opportunity to introduce reforms that entrench neo-liberal economic policies, which are presented as strategies to counter corruption. In Burundi, the privatization of state economic concerns did not reduce corruption, but led to key public resources being captured by political elites or external actors. In effect, the liberal peace has not altered the neopatrimonial character of the state. Structural violence remains, as the masses are expected to suffer wage freezes, public sector retrenchment and 'accumulation by dispossession'. ${ }^{\text {xl }}$

The discursive character of liberal peace interventions means that whilst economic liberalization at the state level promoted the self-maximising individual, humanitarian agencies focused on socially engineering peace among rural communities by instituting intra-ethnic cooperation into development projects, though without much 
Forthcoming in NS Megoran, F McConnell and P Williams (eds), 'The geographies of peace: New approaches to boundaries, diplomacy and conflict resolution', I.B. Tauris \& Co Ltd

success. ${ }^{\text {xli }}$ Failure can be attributed to a marked absence of knowledge about how the various ethnic groups co-existed peacefully prior to colonial rule or how people negotiate cross-ethnic alliances, friendships, marriages, and carry out economic transactions below the level of the state.

The key limitation of the liberal peace in Central Africa is its emphasis on strengthening territorial state power by privileging its military arm. This embeds a militarized and patriarchal vision of the state that may not resonate with local cultures of peace. Consequently, state military expenditure has often surpassed social expenditure, even under post-conflict reconstruction situations. Post-war Burundi's military expenditure in 2008 amounted to 3.7 per cent of Gross Domestic Product - the highest in the economic union of the East African Community. ${ }^{\text {llii }}$ Militarism is evident not just in the continued power of the coercive arms of the state, such as the Burundi secret services, but also the widespread use of weaponry to settle minor disputes and the involvement of military peacekeepers in the sexual abuse of local women. ${ }^{\text {xlii }}$

\section{Embedding militarism}

A crucial limitation of the liberal peace in Africa is its failure to de-militarize former conflict zones. Security Sector Reform (SSR) is a universal policy component of the liberal peace that involves the restructuring of the national security apparatus. This includes the demobilizing of rebel armies and militias, integrating them into the national army and security services, and rehabilitating them into society through the provision of economic incentives. In Central Africa, this multi-million dollar process was controlled by the World Bank, which sub-contracted to UN agencies and private military companies. A key component of SSR is the Disarmament, Demobilization and Rehabilitation (DDR) programme, the experience of which, in Burundi and DRC, 
Forthcoming in NS Megoran, F McConnell and P Williams (eds), 'The geographies of peace: New approaches to boundaries, diplomacy and conflict resolution', I.B. Tauris \& Co Ltd

indicates that the policy was seriously flawed in terms of delivering even sustainable negative peace. A consideration of the continued militarism and the prevalence of gender-based violence, in particular sexual violence, in these societies, can illustrate the DDR's inherent weakness.

Despite the implementation of programmes orientated towards peace, the infrastructures of violence were reproduced in four significant ways. First, rebel armies used DDR as an opportunity to augment their numbers -some purely on paper. This was especially the case in Burundi, where numbers were inflated and recruitment continued after peace agreements were signed. Secondly, militias cached their weapons rather than surrender them to the authorities. Burundi rebels CNDD/FDD (National Council for Defence and Democracy - Forces for Defence and Democracy) and Palipehutu/FNL (National Forces for Liberation) brought only a fraction of their arsenal to the demobilization sites. This facilitated the return to the 'bush' of the FNL leadership and rebel skirmishes during and after the 2010 elections. Thirdly, the agreement that allowed senior rebel leaders to retain their rank when they are integrated into the national army meant that those leaders who were responsible for gross crimes against humanity were empowered militarily under peace. In the DRC, these former rebel officers were now formally able to retain control over the spaces they had previously terrorised through the continuation of direct violence, now sanctioned by the state. Here, the failure to incorporate situated knowledge in DDR increased the people's vulnerability to direct violence. Finally, cash payments were given to former fighters, at the same time as benefits to citizens were reduced, through the introduction of cost-recovery in essential services, such as hospitals and schools. This signals the importance of military values within the new, post conflict society, underpinned by patriarchy and a violent form of hegemonic masculinity. In 2006, Burundi’s heads of police and intelligence were the generals from the rebel armies, where they were not guided by any formal code of 
Forthcoming in NS Megoran, F McConnell and P Williams (eds), 'The geographies of peace: New approaches to boundaries, diplomacy and conflict resolution', I.B. Tauris \& Co Ltd

conduct. The UN representative in charge of human rights pointed to the 'military and elected officials' abuse of local people' and remarked: 'because they are elected they feel that they have the authority to do what they like'. xliv

One outcome of this militarized peace in Central Africa is the prevalence of gender-based violence (GBV) long after conflict has ended and peacebuilding has started. This is due partly to the persistence of rebel activity, especially amongst those groups that were excluded from or were formed after the peace process started. In Burundi, the evidence indicates that GBV, especially rape, was even more widespread in the post-war context than it was before and during the war. ${ }^{\text {xlv }}$ Reported cases of rape rose dramatically after the peace agreement with most of the perpetrators were community members known to the victims. The NGO, Ligue Iteka saw cases rose from 983 in 2003 to 1,791 in 2005. Another NGO, Nturengaho, reported 93 cases in 2003 and 446 cases in 2004, 40 per cent of which were committed by armed personnel. Centre Seruka - a rape crisis centre - received 1,119 cases between September 2003 and 2004. ${ }^{\text {lvi }}$ Burundi' human rights organizations attribute this to the demobilization of young men from the army and the rebel forces.

The scale of sexual violence in Central Africa has led to a flurry of international attention, manifested in outrage in the international media and numerous scoping reports by human rights groups and aid agencies. ${ }^{\text {xlvii }}$ This enormous level of interest has drawn attention to the plight of women and men who have been subjected to extreme forms of abuse. However, the failure to contextualize rape, beyond its representation as 'a weapon of war' among tribal peoples, prevents due consideration of its expansion under a liberal peace framework that promotes militarism and hypermasculinity.

As Pratt and Richter Devore note, the liberal peace intervention to protect women is through providing 'technocratic, legalistic gender mainstreaming and humanitarian relief. ${ }^{,{ }^{x} v i i i}$ In the case of GBV, this involves immediate and palliative health 
Forthcoming in NS Megoran, F McConnell and P Williams (eds), 'The geographies of peace: New approaches to boundaries, diplomacy and conflict resolution', I.B. Tauris \& Co Ltd

care for the victims, which is, no doubt, of critical importance. The other main focus is on the legislative space, holding leaders to account at the International Criminal Tribunal for Rwanda (ICTR) ${ }^{\text {xlix }}$ and reforming the laws of the country concerned so that perpetrators of sexual violence can be punished. Nowrojee criticizes the ICTR for not taking sexual violence seriously, and for conducting investigations that dehumanize, demean and marginalize the victims, with excessive interrogations and no post-trial support. ${ }^{1}$ Such interventions leave the structural causes of wars unexamined.

Even though the liberal peace at the national level is antithetical to women's welfare, its advocates, nevertheless, champion women's rights at the international and regional level, where gender is articulated as a legitimate and a non-political field of action. At the turn of the twenty first century, international discourse altered to incorporate women as agents of peace and to mainstream principles of gender equality into international peacekeeping and peacebuilding. ${ }^{\text {li }}$ This new policy framework is reflected in the UN Security Council Resolution 1325 (2000), which recognises the specific experiences of women during wartime, and advocates a role for women in peacekeeping. Resolution 1325 urges states to end impunity and to prosecute those responsible for sexual violence and other forms of violence against women and girls. UN agencies were able to proactively support local women's organizations mobilizing for peace in Burundi and in the Congo. ${ }^{\text {lii }}$ However, according to recent research, Resolution 1325 forces women's organizations at the UN to refrain from critiquing militarism and masculinity and, instead, to adopt the hegemonic neo-liberal discourse, which constructs women as enterprising and efficient peace-makers. ${ }^{\text {lii }}$ Olonisakan and Okech draw attention to the inconsistency between the male-dominated security narratives which simultaneously privilege sovereignty and territory within international discourse with the proposals for gender equality in peacekeeping and peacebuilding. ${ }^{\text {liv }}$ They call for total 
Forthcoming in NS Megoran, F McConnell and P Williams (eds), 'The geographies of peace: New approaches to boundaries, diplomacy and conflict resolution', I.B. Tauris \& Co Ltd

transformation of the security and governance architecture, if women's rights are to be realised.

\section{Towards an African conceptualization of peace}

So far, I have argued that the liberal peace in Central Africa has failed to recognize the lived material experiences of Africans and local political and cultural dynamics at the expense of realising sustainable peace. The continued presence of structural violence and the proxy wars fought on the African continent informed Hansen's call for Africans to reject a position on peace where it is understood as the peace of Europe and North America and to replace it with an 'African perspective', that is concerned, not merely with 'the resolution of conflicts [but with] the transformation of the extant social systems at both national and international levels. ${ }^{\text {lv }}$ Hansen argues for a perspective on peace that 'makes it possible for the majority of the people on this planet to enjoy physical security, a modicum of material prosperity, the satisfaction of the basic needs of human existence, emotional well-being, political efficacy and psychic harmony. ${ }^{\text {, vi }}$ Linking the liberal peace with the increasingly hollow concept of 'human security' appears to meet this demand theoretically. However, the continued assumption that universal human well-being can be achieved within the extant social system, despite evidence to the contrary, serves to limit its transformative potential. Similarly, while there is much of value in the modern concept of universal rights, for neo-realists such rights continue to be underpinned by notions of differential human worth, which are reinforced by unequal power relations in the global order. The questions now are: Can Africans continue to rely on frameworks that do not reflect their histories, cultures and everyday realities and that are nonparticipatory? And what would an African perspective on peace look like?

Under neo-liberal governance, peace is promoted by a multiplicity of actors: the UN, western governments and their militaries, international and African-based NGOs, 
Forthcoming in NS Megoran, F McConnell and P Williams (eds), 'The geographies of peace: New approaches to boundaries, diplomacy and conflict resolution', I.B. Tauris \& Co Ltd

private military contractors, multinational corporations and Africa's political elites. Most ascribe themselves the mantle of mediators, acting on behalf of the people who are depicted as disenfranchised victims. These actors do not necessarily share a common understanding of the complex dynamics of the violence and they often seek to champion particular individuals or groups, and even enter the process for their own vested interest. ${ }^{\text {lvii }}$ To ensure locally appropriate blueprints for post-war societies, the African body politic has to be incorporated into the peace process in its locally contingent and culturally diverse forms.

Within Africa, cultural differences and local histories of state formation and colonial legacies make a monolithic African perspective on peace unworkable. ${ }^{\text {lvii }}$ However, one can start with the commonalities exposed by the limits of the liberal peace. A locally contingent peace needs to unpack the gendered dynamics of war and peace, and open up to the everyday lived experiences of people with respect to conflict resolution and peaceful co-existence in different geographical and cultural contexts. An African understanding of peace therefore necessitates considering how societies were organised prior to modernity and what constitutes social healing prior to contemporary religious practices and justice systems. Attention to African traditional cultures allows for, as OseiHwedie and Abu-Nimer note, a new approach 'associated with and promoted by diversity' and which 'emphasises open-mindedness, continuous learning and mutual acceptance. $^{\text {lix }}$

All African societies had mechanisms for resolving conflict, and for punishing those who transgressed the rules and norms of the society. Some of these punitive measures would now be considered barbaric, especially when they result in death through torture, and when viewed uncritically. However, these justice systems tended to be representative of the community, especially in acephalous societies and in some monarchical systems they were separated from the monarchy. Pre-colonial African 
Forthcoming in NS Megoran, F McConnell and P Williams (eds), 'The geographies of peace: New approaches to boundaries, diplomacy and conflict resolution', I.B. Tauris \& Co Ltd

justice systems were largely participatory and maintained the social order and the health

of the social body. ${ }^{\text {lx }}$ The denigration of indigenous justice systems as 'backward', along with attempts to control them by successive colonial and post-colonial states, has led to a mixed picture of resistance and resilience in some localities and in others delegitimization among the people. ${ }^{\text {xi }}$

Many Africans can identify indigenous notions of peace in the philosophical tradition known as ubuntu (I am because we are) in Southern Africa and utu and umunthu in East and Central Africa whilst other variations exist across the continent. Ubuntu exists in strong contrast to the individualism of modernity. It refers to the concept of a common humanity - that the essence of being human is dependent on the individual being part of a community ${ }^{1 x i i}$. Murithi identifies ubuntu key principles: empathy, reciprocity, inclusivity, 'cooperation in efforts to resolve common problems' and 'a sense of a shared destiny between people. ${ }^{\text {Ixiii }}$ The epistemological basis for ubuntu was undermined by the arrival of colonial modernity and its vision of progress. Africans were encouraged or forced to discount their understandings of what it means to be humans, to live together harmoniously, and how to protect themselves in times of individual and group insecurity. Under the principles of $u b u n t u$, Murithi notes 'a law-breaking individual thus transforms his or her group into a law-breaking group. ${ }^{\text {Ixiv }}$ Therefore, perpetrators of violence, in order for themselves and their kin-group to be re-admitted into their community, have to go through a process of confessing responsibility or guilt, requesting forgiveness from the victim and his/her kin-group (who is encouraged to show mercy), and pay compensation before the families are reconciled and harmony is restored to the community. Unless such processes have taken place, kin-groups are stigmatized and communities fracture. What is central to these systems is thus communal accountability and participation. 
Forthcoming in NS Megoran, F McConnell and P Williams (eds), 'The geographies of peace: New approaches to boundaries, diplomacy and conflict resolution', I.B. Tauris \& Co Ltd

The Truth and Reconciliation Commission (TRC) in South Africa, devised by Archbishop Desmond Tutu as a means of forgiveness and healing for the fractured and traumatized post-Apartheid society, drew on traditional African concepts of ubuntu. The success of the TRC was hailed as a model that could be adopted elsewhere in Africa. However, in South Africa, ubuntu has been subjected to criticism, especially by the left, as it appears to have been co-opted by neo-liberal forces. ${ }^{\mathrm{kx}}$ And, the TRC has also been criticized for not considering the difficulties women experience in using such public fora to recall their abuses and its non-contextualized application elsewhere on the continent ignores the complexities of local dynamics. ${ }^{\text {lxvi }}$ In Burundi, where many of those who would be culpable for crimes against humanity are incorporated into the ruling and main opposition parties, the prospect of them developing a mechanism that would expose their own criminality is limited. Hence, the government's foot-dragging, agenda change, and the constraining of the power of the TRC proposed in the peace agreement, as the state response to donor pressure. Even if implemented, this top-down imposition of reconciliation will fail to reunite and heal those affected. Macdonald proposes the wresting of ubuntu from neo-liberal forces and reviving a 'more radical ubuntu discourse' by sticking to its ideals of collective action. He states: 'to be true to ubuntu ideals collective process is as important as its collective product. ${ }^{\text {,lxvii }}$ Therefore, ubuntu offers a more fitting alternative to the individualism of neo-liberalism, since it largely reflects the pre-modern, as well as the everyday practices of peace among many African communities.

The collapse of the modern justice systems during late twentieth century wars, along with the scale of the violence, has compelled proponents of the liberal peace to encourage a return to traditional systems of justice, such as the bashingantahe of Burundi and the Gacaca courts of Rwanda. As Ingelaere notes, the basic principles of these traditional institutions are the establishment of accountability and fostering reconciliation 
Forthcoming in NS Megoran, F McConnell and P Williams (eds), 'The geographies of peace: New approaches to boundaries, diplomacy and conflict resolution', I.B. Tauris \& Co Ltd

at the local scale. ${ }^{\text {lxviii }}$ However, despite the potential benefits of using African value systems in contemporary justice mechanisms, it would be naïve to assume that one could fully replicate such justice systems within the modern context, or that they would be representative, especially if their restitution and the form they adopt are determined by the state and funded by aid donors. These 'modern' traditional systems tend to reflect the patriarchal nature of the national state, uphold the priorities of the political elite rather than those of the people, and are less effective in resolving conflicts for women and, according to Thomson, 'may exacerbate local power dynamics and social and political inequalities.' lxix

African people's attitudes to the militarized body are in stark contrast to the assumptions made by western peace experts that, given monetary payments, soldiers can be rehabilitated into their local communities. Recent research highlights the social abhorrence to the militarized body that pervades certain cultures in Africa. In Northern Uganda, DRC and Burundi, known association with rebels makes one an outcast in the society. ${ }^{\mathrm{lxx}}$ Former soldiers continue to be feared and, in turn, terrorize communities, using gender-based violence as a strategy for re-establishing the power associated with the hyper-masculinity of wartime. The stigmatization of soldiers and rebels who are known to have committed acts of atrocities is found in many local communities and signifies a rejection of militarist ideology, yet post-conflict reconstruction enhances excombatants' material and physical power in peacetime. This stigmatization can be destructive because it extends to all those who have been implicated in acts of extreme violence, whether bush wives, child soldiers or rape victims. However, an examination of the healing processes would allow for greater African agency in effecting peace at a local level. This should be concomitant with understanding how non-violent forms of masculinity are performed within these societies. 
Forthcoming in NS Megoran, F McConnell and P Williams (eds), 'The geographies of peace: New approaches to boundaries, diplomacy and conflict resolution', I.B. Tauris \& Co Ltd

Finally, the content of an African feminist perspective has to be different from the non-emancipatory women-centred activities of the liberal peace. So far, African women's campaigns for greater participation in peace processes have tended to perpetuate essentialist notions of women as natural peace-makers. As Diop claims, the assumption is that 'women are better equipped than men to prevent or resolve conflicts' because they 'are excessively affected by war and should be playing a fundamental role in reconciliation, reconstruction and rehabilitation, ${ }^{\text {,kxi }}$ thereby implying that women possess some innate suitability for peace negotiations.

Africa's regional organizations, under pressure from women's NGOs, western donors and institutions, have adopted protocols to address gender issues in peace and security. One example is Article 10 (1) of the African Union's Protocol to the African Charter on Human and Peoples' Rights on the Rights of Women, which stipulates that 'all women have the right to a peaceful existence and the right to participate in the promotion and maintenance of peace.' lxxii Other regional organizations, such as Southern African Development Community and the Economic Community of West African States, have also produced their own protocols. However, such legislation, though enlightening, has not been localised and, where the national state is structured around patriarchy and militarism, attention to gender issues beyond women's numerical representation in government, remains limited. African feminist scholars have criticized the dis-empowering role of elite women who have been co-opted into militarized institutions. ${ }^{\text {lxxiii }}$ Olonisakan and Okech call for a reform of African women's organizations in order to prevent the mobilization of gender-identities (mothers, sisters, and wives) by the masculinized states, elite women and humanitarian actors..$^{\text {lxiv }}$

By not paying attention to local cultures of difference, measures towards gender equality in the liberal peace run the risk of essentializing A frican women. For example, Burundian women had diverse war experiences, based on ethnicity, class, location (urban 
Forthcoming in NS Megoran, F McConnell and P Williams (eds), 'The geographies of peace: New approaches to boundaries, diplomacy and conflict resolution', I.B. Tauris \& Co Ltd

or rural) and association with state or rebels (bush wives or fighters) forces. Equally, their interpretation of peace is also differentiated. Blanchard's suggestion that 'the identification of women with peace be balanced by recognition of the participation, support and inspiration women have given to war making', requires detailed consideration. ${ }^{\text {lxv }}$ Despite the popularity of the discourse on African women as victims in wartime, there is widespread evidence to suggest that some women participated in genocide and sexual violence against other women. African Rights documents how Hutu women in Rwanda identified people to be killed. They contend that educated women, who held government positions, bore 'a special responsibility for the breadth and depth of women's participation in the killings'. ${ }^{\text {xxvi }}$ Women parliamentarians, councillors and mayors were willing to order the killing of Tutsi girls and the Tutsi children of Hutu women married to Tutsi men.

Women were also able to take on very proactive roles as fighters and community leaders. In the DRC, Peuchguirbal shows how 'war provided Congolese women with opportunities as well as burdens. They took up leadership positions and revived local networks. They were not mere victims as they fought for their survival. . $^{\mathrm{lx} x \mathrm{ii}}$ In the absence of men, war can liberate women from the patriarchal straitjacket. Wars expose the false dichotomy between the public and the private, and force women and their interests into the spotlight. Essentially, the view of African women in the liberal peace as universal victims runs counter to local realities.

An African feminist perspective on peace demands recognition of class and cultural differences between African women across the continent, whilst asserting that peace requires a dismantling of the patriarchal state, but, at the same time, noting how oppressions of race, gender and place intersect at the global level to dis-empower African men and women together. First and foremost, this means being critical about those cultural traditions that deny women's agency. African feminist scholars have started to 
Forthcoming in NS Megoran, F McConnell and P Williams (eds), 'The geographies of peace: New approaches to boundaries, diplomacy and conflict resolution', I.B. Tauris \& Co Ltd

revisit the past to examine gender relations in pre-colonial matriarchal societies, in order to understand 'the role a matriarchal moral philosophy' might play in constructing locally appropriate [gender equality] in contemporary African politics and society. ${ }^{\text {lxxviii }}$ The goal is a more grounded, non-hierarchical and emancipatory vision of peace for women and men.

\section{Conclusion}

In Central Africa, the liberal peace has delivered neither positive nor sustainable negative peace. From its origins in the Euro-American political experience the liberal peace has become globally hegemonic, and has remained so because of its intersection with the geopolitical interests of western states and neo-liberal capitalism. On top of its geographic specificity, its embodiment of a gendered and militarist conceptualization of national security make it increasingly less appropriate for non-western societies, where peace requires far-reaching emancipatory politics. The major limitations of the liberal peace as implemented in the Central African region is its emphasis on a militarized interpretation of national security with its negative implications for the well-being of citizens, especially under conditions where the institutions of governance, and the material conditions of life, are weak and impoverished respectively. Peace and demilitarization necessitate concomitant transformation in the socio-economic system, new forms of state/society relationships and alternative forms of masculinity. These must be based on an acceptance of diversity and a recognition of how the intersections between race, ethnicity and gender at the local, national and global levels shape policy responses.

Unearthing alternative geographies of peace requires challenging the structural inequalities and the racialized and gendered discourses that are embedded in contemporary framings of the hegemonic liberal peace. It requires an ontological and epistemological shift in our understanding of the social body and more contextualized 
Forthcoming in NS Megoran, F McConnell and P Williams (eds), 'The geographies of peace: New approaches to boundaries, diplomacy and conflict resolution', I.B. Tauris \& Co Ltd

and critical research that at the outset privileges local experiences of peaceful co-

existence. So far, local mechanisms for peace have been co-opted and re-shaped by state

elites and the external peace industry. Progressive scholars need to push for greater

engagement of local communities in a collective framing of the peace process from the

bottom-up. A localised and gender-sensitive peace has the capacity to fashion a post-war

society that gives prominence to the well-being of all African peoples and challenges the

dehumanizing conditions that Africans have been socialized into accepting as the norm.

Here, recognizing and drawing on the contribution of African feminists is an essential

prerequisite for peace.

\footnotetext{
${ }^{\mathrm{i}}$ Steans, Jill, Gender and International Relations: An Introduction (New Brunswick, NJ, 1998); Enloe, Cynthia, 'Demilitarization - or more of the same? feminist questions to ask in the postwar moment', in C. Cockburn and D. Zarkov (eds), The Post-war Moment: Militaries, Masculinities and International Peacekeeping (London, 2002)

${ }^{\text {ii } W i l l i a m s, ~ P h i l i p p a ~ a n d ~ M c C o n n e l l, ~ F i o n a, ~ ' C r i t i c a l ~ g e o g r a p h i e s ~ o f ~ p e a c e ' ~ A n t i p o d e ~ 43 / 4 ~(2011), ~ p . ~} 2$

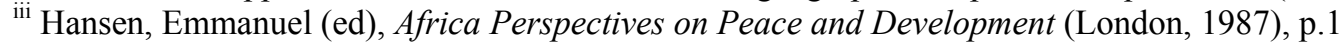

iv Dalby, Simon, 'Gender and critical geopolitics: reading security discourse in the new world disorder' Environment and Planning D: Society and Space 12/5 (1994), pp. 595-612; Hyndman, Jennifer, 'Beyond either/or: a feminist analysis of September $11^{\text {th.' }} A C M E 2 / 1(2003)$, pp. 1-13

${ }^{\vee}$ Hyndman: 'Beyond either/or', pp. 1, 3

vi Megoran, Nick, 'War and peace? An agenda for research and practice in geography', Political Geography 30/4 (2011), p.185

vii Daley, Patricia, Gender and Genocide: The Search for Spaces of Peace in Central Africa (Oxford, 2008) Lemarchand, Rene, The Dynamics of Violence in Central Africa (Philadelphia, 2009)

viii Burundi's Arusha peace and reconciliation agreement was signed in 2000 after almost three years of negotiation. DRC's Lusaka peace agreement was signed in 1999. In both countries, the peace agreements were followed by numerous ceasefire agreements with various rebel groups. Two successive democratic elections have been held in these countries.

${ }^{\text {ix }}$ Gibbing, Sheri Lynn, 'No angry women at the United Nations': Political Dreams and the Cultural Politics of United Nations Security Council Resolution 1325' International Feminist Journal of Politics 13/4 (2011), pp.522-538

' Ingelaere, Bert, 'Does the truth pass across the fire without burning?' locating the short circuit in Rwanda's Gacaca courts' Journal of Modern African Studies, 47/4(2009), p.516

${ }^{\mathrm{xi}}$ Hill Collins, Patricia, Black Feminist Thought: Knowledge, Consciousness and the Politics of Empowerment (Perspectives on Gender) (New York, London, 2000), p.18

${ }^{x i i}$ Duffield, Mark, Global Governance and the New Wars: The Merging of Development and Security (London, 2001); Kaldor, Mary, New and Old Wars: Organized Violence in a Global Era (Cambridge, 2001)

xiii Kaldor: New and Old Wars

xiv Weber, Max, Economy and Society (Berkeley, 1978)

xv Steans, Jill: Gender and International Relations; p.107
} 
${ }^{\text {xvi }}$ Gramsci, Antonio, Prison Notebooks (Bodmin and Kings Lynn, 2007)

xvii Gramsci: Prison Notebooks, p.12

xviii Keenan, Jeremy, 'Terror in the Sahara: the implications of US imperialism for North and West Africa' Review of African Political Economy 31/101 (2004), pp. 475-496

${ }^{\text {xix }}$ Galtung, Johan, 'Violence, peace \& peace research' Journal of Peace Research 6/3 (1969), pp. 167191

${ }^{\mathrm{xx}}$ Melvern, Linda. R., A People Betrayed: The Role of the West in Rwanda's Genocide (London, 2000)

${ }^{x \times i}$ See UN Security Council, 'Regarding the events that occurred at Gatumba', , S/2004/821

(http://www.un.org/Docs/sc/unsc_presandsg_letters04.html, 2004), and International Crisis Group, Maintaining Momentum in the Congo: The Ituri Problem ( Nairobi/Brussels, 2004)

xxii Confortini, Catia C., 'Galtung, violence, and gender: the case for a Peace Studies/feminist alliance' Peace \& Change 31/3 (2006), pp. 333-367; Hudson, Heidi, 'Peacebuilding through a gender lens and challenges of implementation in Rwanda and Cote d'Ivoire' Security Studies 18/2 (2009), pp. 287-318. xxiii Enloe, Cynthia, Manoeuvres: the International Politics of Militarizing Women's Lives, (Berkeley \& Los Angeles, 2000); Steans: Gender and International Relations; Yuval-Davis, Nira, Gender and Nation (London, 1997)

${ }^{\text {xxiv }}$ Messerschmidt, James W., Masculinities and Crime: Critique and Reconceptualization of Theory (Lanham, Md, 1993)

${ }^{\mathrm{xxv}}$ Daley: Gender and Genocide; Hudson: 'Peacebuilding through a gender lens'

${ }^{x x v i}$ Enloe: 'Demilitarization - or more of the same?'; Simić, Olivera, 'Does the presence of women really matter? towards combating male sexual violence in peacekeeping operations' International Peacekeeping 17/2 (2010), pp.188-199; Hudson: 'Peacebuilding through a gender lens.'

xxvii Yuval-Davis: Gender and Nation

xxviii Hill Collins: Black Feminist Thought

${ }^{x x i x}$ Foucault, Michel Society must be Defended (London, 2004), pp. 253-256

${ }^{\mathrm{xxx}}$ Fluri, Jennifer, 'Foreign-Passports only': geographies of (post) conflict work in Kabul, Afghanistan' Annals of the Association of American Geographers 99/5 (2009), pp. 986-994

${ }^{x x x i}$ Dallaire, Romeo, Shake Hands with the Devil: The Failure of Humanity in Rwanda (London, 2004), p. 522

xxxii Crowder, Michael, 'Whose dream was it anyway? Twenty-five years of African independence' African Affairs 86/342, (1987), pp. 7-24

xxxiii The nationalist leaders, Julius Nyerere and Kwame Nkrumah, who experimented with methods of social tolerance and nation-building in multi-ethnic and multi-cultural states, were criticized by the West for their socialist policies, despite their success at forging national unity.

${ }^{\text {xxxiv }}$ Richmond, Oliver, 'Becoming liberal, unbecoming liberalism: liberal-local hybridity via the everyday as a response to the paradoxes of liberal peace building' Journal of Intervention and State Building 3/3 (2009), p.330

xxxv Kaldor: New and Old Wars

${ }^{\text {xxxvi }}$ Collier, Paul and Hoeffler, Anke, 'Greed and grievance in civil war' Oxford Economic Papers 56 (2004), pp.563-595

xxxvii Tull, David M. and Mehler, Andreas, 'The hidden cost of power sharing: reproducing insurgent violence in Africa' African Affairs 104/416 (2005), pp. 375-398; Mehler, Andreas, 'Peace and power sharing in Africa: not so obvious a relationship' African Affairs 108/432 (2009), pp.453-473

xxxviii Tull and Mehler: 'The hidden cost'

${ }^{\text {xxxix }}$ Eriksen, Stein S., 'The liberal peace is neither: peace building, state building and the reproduction of conflict in the Democratic Republic of Congo' International Peacekeeping 16/5 (2009), pp.652-666; Austerre, Séverine, 'Hobbes and the Congo: frames, local violence and international intervention' International Organization 63/Spring (2009), pp. 248-80

${ }^{\mathrm{xl}}$ David Harvey, The New Imperialism (Oxford, 2003) Ch.4. , coined the term to explain the contemporary practices of primitive accumulation as carried out by hegemonic capitalist states and multinational corporations in the global periphery; and see Daley: Gender and Genocide, for a discussion of accumulation by dispossession with respect to Burundi

${ }^{\mathrm{xli}}$ Vervisch, Thomas, 'The solidarity chain: post-conflict reconstruction and social capital building on three Burundian hillsides' Journal of Eastern African Studies 5/1 (2011), pp. 24-41

xlii Oluoch, Fred, 'Burundi's "smallest" military budget highest as fraction of GDP in region' The East African 12 April 2010 
Forthcoming in NS Megoran, F McConnell and P Williams (eds), 'The geographies of peace: New approaches to boundaries, diplomacy and conflict resolution', I.B. Tauris \& Co Ltd

xliii Clayton, Jonathan and Bone, James, 'Sex scandal in Congo threatens to engulf UN's peacekeepers' The Times, 23 December 2004. Retrieved 6 October 2011, from

http://www.timesonline.co.uk/tol/news/world/article405213.ece; Simić: 'Does the presence of women really matter?'

xliv Interview conducted with head of the human rights section of the UN mission in Burundi (ONUB), June 2006

${ }^{x l v}$ The increase in the number of reported rape could also have been attributed to better data gathering exercises in the post-war period, as donors allocated resources to tackle GBV, and it was accepted that because of the stigma associated with rape, under-reporting was widespread and the scale of sexual violence was far greater.

xlvi Data collected from Ligue Iteka, Déclaration de la Ligue ITEKA: Violence Certaines Localités $d u$ Burundi I (Bujumbura, 2005). Accessed December 2005 from Http://www.ligue-iteka.africa-web.org/, and during interviews with representatives of Ligue Iteka, Médecin sans Frontières, Nturengaho and Centre Seruka, June 2006.

xlvii See, for example, Réseau des Femmes pour un Développement Associatif(RFDA), Réseau des Femmes pour la Défense des Droits et la Paix (RFDDP) and International Alert (IA), Women's Bodies as a Battleground: Sexual violence Against Women and Girls During the war in the Democratic Republic of Congo, South Kivu (1996-2003) (London, 2005), and Eriksson-Baaz Maria and Stern, Maria, The Complexity of Violence - A critical analysis of sexual violence in the DRC (Uppsala, 2010) xlviii Pratt, Nicola and Richter-Devore, Sophie, 'Critically examining UNSCR 1325 on Women, Peace and Security' International Feminist Journal of Politics 13/4 (2011), pp. 498-499

${ }_{\text {xlix }}$ ICTR, based in Arusha Tanzania, was established by United Nations Security Council resolution 955 of 8 November 1994 and resolution 977 of 22 February 1995 to perpetrators of the I994 Rwandan genocide.

${ }^{1}$ Nowrojee, Binaifer, 'Your justice is too slow: will the ICTR fail Rwanda's rape victims?' (Geneva, 2005)

${ }^{l i}$ Olonisakan, Funmi and Okech, Awino, Women and Security Governance in Africa (Cape Town, Dakar, Nairobi and Oxford, 2011)

${ }_{\text {lii }}$ Burke, Enid de Silva, Klot, Jennifer and Bunting, Ikaweba, Engendering Peace: Reflections on the Burundi Peace Process (Nairobi, 2001); Puechguirbal, Nadine, 'Women and war in the Democratic Republic of Congo' Signs: Journal of Women in Culture and Society 28/4 (2003), pp. 1271-1281

liii Gibbing: 'No angry women at the United Nations'; Pratt, Nicola and Richter-Devore, Sophie, 'Critically examining UNSCR 1325 on Women, Peace and Security' International Feminist Journal of Politics 13/4 (2011), pp. 489-503

liv Olonisakan and Okech: Women and Security; Pratt and Richter-Devore, 'Critically examining UNSCR $1325^{\prime}$, pp. 498-499

${ }^{\text {Iv }}$ Hansen: Africa Perspectives on Peace

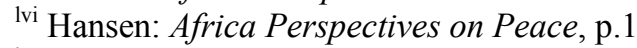

Ivii Daley: Gender and Genocide

lviii Hudson: 'Peacebuilding through a Gender Lens'

lix Osei-Hwedie, Bertha Z. and Abu-Nimer, Mohammed, 'Editorial: Enhancing the positive contributions of African culture' Peace building and Development 4/3 (2009), p.2

${ }^{1 \times}$ Diop, Cheikh Anta, Precolonial Black Africa: A Comparative Study of the Political and Social systems of Europe and Black Africa, from Antiquity to the Formation of Modern States (London, 1987) and The Cultural Unity of Black Africa: the Domains of Matriarchy \& Patriarchy in Classical Antiquity (London,1989)

${ }^{1 \mathrm{lxi}}$ Herbst, Jeffrey, States and Power in Africa (Princeton, NJ, 2000)

lxii Ramose, Mogobe. B., 'The Philosophy of Ubuntu and Ubuntu as a Philosophy', in P. H. Coetzee, and A. P. J. Roux (eds) Philosophy from Africa (2nd edn.) (Cape Town, 2002) pp.230-238

lxiii Murithi, Tim, ‘An African .perspective on peace building: Ubuntu lessons in reconciliation' International Review of Education 55 (2009), pp.225, 227

Ixiv Murithi: 'An African perspective', p. 227

Ixv MacDonald, David, 'Ubuntu bashing: the marketisation of 'African values' in South Africa' Review of African Political Economy 37/124 (2010), pp. 139-152

${ }_{1 \times 1 \mathrm{i}}$ Ross, Fiona, Bearing Witness: Women and the Truth and Reconciliation Commission in South Africa (London, 2003); Borer, Tristan Anne, 'Gendered war and gendered peace: truth commissions 
Forthcoming in NS Megoran, F McConnell and P Williams (eds), 'The geographies of peace: New approaches to boundaries, diplomacy and conflict resolution', I.B. Tauris \& Co Ltd

and post-conflict violence: lessons from South Africa' Violence Against Women 15 (2009), pp.11691193

Ixvii MacDonald: 'Ubuntu bashing', p.149

Ixviii Ingelaere: 'Does the truth pass'

Ixix Thomson, Susan 'The darker side of transitional justice: the power dynamics behind Rwanda's Gacaca courts' Africa 81/3 (2011), p.386

${ }^{1 x x}$ Eriksson-Baaz and Stern: The Complexity of Violence; Wilhelm-Solomon, Matthew, Displacing AIDS: Therapeutic Transitions in Northern Uganda (Oxford, 2011)

lxxi Diop, Bineta, 'Engendering the peace process in Africa: women at the negotiating table' Refugee Survey Quarterly 21, (2002), p. 143

Ixxii The Protocol to the African Charter on Human and Peoples' Rights on the Rights of Women was adopted by the second summit of the African Union on 11 July 2003 in Maputo, Mozambique. It came into force in October 2005 after it was ratified by the $15^{\text {th }}$ member state

${ }^{1 x x i i i}$ For example, the UN Commission on the Status of Women and the OAU co-sponsored the organization of the 'First Summit of First Ladies for Peace and Humanitarian Issues', held in Abuja, Nigeria, 5 - 7 May 1997.

${ }^{\text {lxxiv }}$ Olonisakan and Okech: Women and Security

${ }^{\mathrm{lxxv}}$ Blanchard, Erica M. 'Gender, international relations, and the development of feminist security theory', Signs: Journal of Women in Culture and Society, 28/4: (2003), p.1290

${ }^{1 x x v i}$ African Rights, Not So Innocent: When Women Become Killers (London, 1995), p.2

Ixxvii Puechguirbal, Nadine, 'Women and war', p. 1274

Ixxviii Amadiume, Ifi, Reinventing Africa: Matriarchy, Religion, and Culture (London, 1997), p.157 